\title{
KWESTIA PIERWOTNOŚCI FUNKCJI ESTETYCZNEJ MUZYKI W ŚWIETLE ZNALEZISK ARCHEOLOGICZNYCH
}

\author{
THE ISSUE OF THE PRIMORDIALITY \\ OF THE AESTHETIC FUNCTION OF MUSIC \\ IN THE LIGHT OF ARCHEOLOGICAL DISCOVERIES
}

\author{
Piotr Podlipniak \\ orcid.org/0000-0002-4326-559X \\ Instytut Muzykologii, Uniwersytet im. Adama Mickiewicza \\ ul. Uniwersytetu Poznańskiego 7, 61-614 Poznań \\ podlip@amu.edu.pl
}

\begin{abstract}
Bony flutes dated back to around 43,000 years old are the clearest examples of musical instruments ever found. There are also other archeological artifacts related to the possible musical activity of Homo sapiens and Homo neanderthalensis, which are the subject of numerous controversies. Bearing in mind that singing is the simplest form of musical activity that does not need any tools, the beginning of music must have been much older than the first musical instruments. Due to the fact that the sonic results of prehistorical hominins' musical activity have not been preserved, the question of the artistic nature of hominins' music requires the ethological knowledge as well as archeological findings. One of the widely discussed ethological hypotheses concerning human proclivity to behave artistically is the idea of artification, which has been proposed by Ellen Dissanayake. This idea suggests that the source of the human proclivity for art is the species-specific predisposition of Homo sapiens to transform the mundane non-artistic phenomena into art. However, while in the case of visual arts, the archeological discoveries of prehistorical paintings are by themselves the proof of such transformation in order to recognize the aesthetic function of our ancestors' sound expressions the interpretation of the archeological discoveries of musical instruments in a broader context seems to be indispensable. The main aim of this article is to indicate that communication that has led to social consolidation has been the primordial function of music. Only together with the accelerating cultural evolution that occurred at the end of the middle Paleolithic period, musical activity was transformed from a simple communicative tool into an aesthetic phenomenon. It is proposed that this transformation could have been possible thanks to the appearance of the proclivity to artification.
\end{abstract}

KEY WORDS: artification, bony flutes, lithophones, primordial function of music, sound communication 
Muzyka rozumiana jako rezultat specyficznej aktywności behawioralnej człowieka jest zjawiskiem, które przez zdecydowanie większą część historii naszego gatunku utrwalane było i przekazywane jedynie $\mathrm{w}$ tradycji oralnej. $\mathrm{Z}$ tej przyczyny wszelkie twierdzenia zarówno o początkach muzyki, jak i o jej pierwotnych funkcjach budowane są wyłącznie na podstawie pośrednich źródeł wiedzy. Źródła te ze swej natury nie dają możliwości stworzenia pełnego i wyczerpującego obrazu pierwotnej muzyczności ${ }^{1}$ naszych przodków, co stwarza przestrzeń dla licznych spekulacji. Równie istotnym problemem dla badań nad muzycznością człowieka jest ustalenie, jakie faktyczne zjawiska kryją się pod pojęciami „muzyka” i „muzyczność”. Zagadnienie definicji „muzyki” i „muzyczności” wydaje się nabierać w refleksji nad pierwotną funkcją muzyki kluczowego znaczenia ze względu na konieczność precyzyjnego odróżniania zachowań muzycznych od innych form aktywności dźwiękowej człowieka, jak też na międzydziedzinowy charakter pytania o funkcję muzyki. Problem ten wiąże się bowiem z jednej strony z pytaniem o biologiczny charakter zachowań muzycznych, a z drugiej dotyka zjawisk stanowiących przedmiot badawczy tradycyjnie rozumianych nauk społecznych i humanistycznych, co prowadzić może niekiedy do trudności z pogodzeniem twierdzeń formułowanych przez przedstawicieli tych nauk w ramach często odrębnych paradygmatów.

Jedną z takich nieprzezwyciężalnych trudności wydaje się definiowanie muzyki przez wielu humanistów oraz przedstawicieli nauk społecznych nie za pomocą wskazania na cechy dystynktywne tego zjawiska, ale przez przyjęcie społecznego, zmiennego kulturowo i historycznie rozumienia tego, co opisywane jest tym pojęciem, czyli akceptację tzw. otwartej definicji muzyki (Cook, 2000; Dahlhaus, Eggebrecht, 1992). Innymi słowy według takiego stanowiska za muzykę uważa się wszystko to, co dana grupa społeczna chce nazywać muzyką. Nie trzeba tu wyliczać licznych problemów, jakie rodzi posługiwanie się takim rozumieniem muzyki przy wszelkich badaniach porównawczych, nie tylko interkulturowych, lecz także intergatunkowych, nieuniknionych podczas rozpatrywania pierwotnej funkcji muzyki. Jedynym możliwym rozwiązaniem tego problemu wydaje się przyjęcie w badaniach nad pierwotną muzycznością jednego wspólnego paradygmatu.

\section{MUZYKA Z PERSPEKTYWY PARADYGMATU NATURALISTYCZNEGO}

Dla pogodzenia perspektyw przyrodniczej i humanistycznej jedynym możliwym do przyjęcia paradygmatem jest naturalizm. Nie da się bowiem pogodzić jakichkolwiek poglądów antynaturalistycznych, zakładających z definicji istnienie takiej sfery rzeczywistości, która ze swej natury jest niepoznawalna metodami nauk przyrodniczych, ze współczesną przyrodniczą wizją człowieka opartą na korpuskularno-

${ }^{1}$ Ponieważ słowo „muzykalność” w polskiej terminologii odnosi się do szczególnych uzdolnień muzycznych, które odróżniają część ludzkiej populacji od tej, która ich nie ma, dlatego dla podkreślenia powszechnego charakteru zdolności muzycznych w niniejszym artykule posługuję się słowem „muzyczność”. 
-falowym modelu rzeczywistości. Skoro naturalizm zakłada istnienie jednej rzeczywistości, poznawalnej metodami nauk przyrodniczych, wspomniana otwarta definicja muzyki jest nieprzydatna dla naturalistycznej refleksji nad muzyką (Brown, Merker, Wallin, 2000), z uwagi na brak możliwości zastosowania narzędzi badawczych stosowanych w przyrodoznawstwie w celu rozpoznania ewentualnych, gatunkowo wspólnych, elementów zachowań muzycznych człowieka.

Wspomniana otwarta definicja muzyki nie pozwala bowiem na wykluczenie jakiegokolwiek zjawiska ze zbioru określanego mianem „muzyka”. Nie można przecież wykluczyć, że jakaś grupa społeczna w przyszłości nie będzie chciała nazywać muzyką zjawisk dźwiękowych, które nie mieszczą się na przykład w zakresie słyszalności dostępnej słuchowi ludzkiemu, co zresztą w ograniczonym zakresie ma już miejsce we współczesnej twórczości muzycznej (Roosth, 2018). Choć rezygnacja z otwartej definicji muzyki niesie ze sobą ryzyko wykluczenia pewnej części dzieł współczesnej kultury muzycznej z pojęcia „muzyka”, z ponadczasowej i interkulturowej perspektywy oglądu ludzkich zachowań dźwiękowych, liczba tych zjawisk wydaje się na tyle mała, że można do celów badań nad początkami muzyczności uznać takie przejawy niektórych awangardowych dzieł muzycznych za nieistotne.

Do twórczości takiej zaliczyć należy nie tylko te zjawiska, które wykraczają poza możliwości percepcyjne człowieka, ale także wszystkie takie utwory muzyczne, które pozbawione są co najmniej jednej z powszechnych cech muzyki, takich jak puls muzyczny i związany z nim porządek metryczny muzyki czy dyskretne klasy wysokości dźwięku. Za wykluczeniem takich dzieł jako przykładów muzyki przy próbach jej definiowania przemawia nie tylko stosunkowo ich niewielka liczba w porównaniu z całokształtem twórczości muzycznej ludzkości na przestrzeni dziejów i w perspektywie interkulturowej, ale także niewielkie zainteresowanie społeczne takimi dziełami (Dutton, 2009), brak powszechnej jednoznacznej identyfikacji tych wytworów jako muzycznych, ograniczenie swoim zakresem występowania jedynie do współczesnej kultury muzycznej Zachodu, jak też stosunkowo młody wiek takich ekspresji muzycznych, który nie sięga dalej w historii niż początków XX wieku. Dlatego dla podjętych tu rozważań przyjąć należy, że muzyką jest taka aktywność dźwiękowa człowieka, która polega na porządkowaniu dyskretnych kategorii wysokości dźwięku w czasie i/lub hierarchizacji zjawisk dźwiękowych w czasie w sposób periodyczny i hierarchiczny. Za takim ograniczeniem pojęcia „muzyka” przemawiają wyniki badań, które wskazują na wyjątkowość pod tym względem człowieka wśród innych gatunków zwierząt (Fitch, 2006, 2013; Jackendoff, Lerdahl, 2006). Natomiast pod pojęciem „muzyczności” należy rozumieć tu zestaw zdolności poznawczych człowieka, które umożliwiają mu ekspresję muzyczną (Fitch, 2015).

\section{SPÓR O FUNKCJE MUZYKI}

W tradycji zachodniej muzyka rozumiana jest zwykle jako zjawisko artystyczne, co prowadzi do eksponowania w pierwszym rzędzie w refleksji o muzyce jej funkcji este- 
tycznej. Nawet przez etnomuzykologów i antropologów muzyki, którzy w największym chyba stopniu spośród badaczy muzyki mają świadomość niezwykłego jej zróżnicowania w różnych kulturach, funkcja estetyczna muzyki jest niejednokrotnie traktowana jako prymarna (Merriam, 1964). Inną często wskazywaną funkcją jest komunikacja. Komunikacyjny charakter muzyki stał się wręcz podstawą dla uprawiania odrębnej subdyscypliny muzykologii, jaką jest semiotyka muzyki (Jabłoński, 2010). Wśród innych funkcji muzyki wymienia się też wzmacnianie więzi społecznych (Blacking, 1973; Dunbar, 2012; Storr, 1992; Tarr, Launay, Dunbar, 2014), uprawomocnianie rytuału (Malinowski, 1987), wywoływanie wspomnień autobiograficznych (Cady, Harris, Knappenberger, 2008; Schulkind, Hennis, Rubin, 1999), regulację nastroju (Husain, Thompson, Schellenberg, 2002), w tym łagodzenie stresu (North, Hargreaves, 2000; Thoma i in., 2013) i pokonywanie kryzysów emocjonalnych (Behne, 1997), by wskazać tu tylko na te najczęściej przywoływane. Należy jednak podkreślić, że wskazywane przez przedstawicieli różnych dyscyplin naukowych funkcje muzyki nie muszą odnosić się do muzyczności z tej samej perspektywy metodologicznej, co prowadzić może do wielu nieporozumień. W biologii na przykład czym innym jest określenie funkcji z perspektywy ultymatywnej (dlaczego dane zjawisko istnieje), a czym innym z perspektywy proksymalnej (jak dane zjawisko działa) (Tinbergen, 1963). Jeśli przyjmiemy, na przykład, że muzyka wyewoluowała dzięki działaniu Darwinowskiego doboru płciowego (Darwin, 1871), to, że słuchanie muzyki wzbudza emocje, wskazuje, że z perspektywy proksymalnej funkcją muzyki jest wzbudzanie emocji, ale z perspektywy ultymatywnej tą funkcją jest popis seksualny, który dzięki mechanizmowi wzbudzania emocji prowadzi do sukcesu reprodukcyjnego osobnika. Jak zatem pogodzić w badaniach interdyscyplinarnych łączących tradycyjną etnomuzykologię, antropologię muzyczną, estetykę i semiotykę muzyki z jednej strony i etologię oraz inne dyscypliny przyrodnicze z drugiej? Jednym z możliwych rozwiązań jest próba redukcji czy też wyjaśnienia funkcji muzyki wskazywanych i opisywanych przez przedstawicieli nauk humanistycznych w kategoriach odpowiadających funkcjom wyróżnianym przez etologów. Jak zatem należy rozumieć i odróżnić funkcję komunikacyjną muzyki od jej funkcji estetycznej w kategoriach etologicznych?

Rozpatrując zagadnienie funkcji estetycznej muzyki, dotykamy rozległego problemu doświadczenia piękna muzycznego, który, mimo że od początku filozoficznej refleksji nad muzyką zajmował umysły niezliczonej rzeszy myślicieli, nie doczekał się jak dotąd satysfakcjonującego rozwiązania. Czy zatem coś tak wzniosłego i trudnego do jednoznacznego zdefiniowania może stać się przedmiotem namysłu przyrodniczego? Okazuje się, że kategoria piękna obecna była od dawna w refleksji przyrodniczej, bo już u samego Karola Darwina, który posługiwał się nią, wskazując na niepoślednią rolę wyborów estetycznych osobników w procesie doboru płciowego (Darwin, 1871). I choć w XX-wiecznej historii biologii ewolucyjnej Darwinowskie rozumienie piękna jako zjawiska bezpośrednio związanego z umysłowością zwierząt nie zajmowało należytego mu miejsca, można zaobserwować ostatnimi czasy restytucję idei Darwina na gruncie naturalizmu (Prum, 2017). Jak można zatem zredukować pojęcie piękna do kategorii naturalistycznych? 
Z perspektywy naturalistycznej piękno jest doświadczane dzięki interpretacji bodźców przez układ nerwowy danego osobnika. W przypadku gatunków społecznych, charakteryzujących się zdolnością do uczenia się społecznego (Laland, 2017), odczucie piękna zależy zarówno od własności fizjologicznych tego układu (na które składają się cechy gatunkowo specyficzne, a także ewentualne elementy idiosynkratyczne dla danego osobnika), jak i modyfikacji informacji kulturowej, jaka dokonuje się w środowisku społecznym danego osobnika. Co ważne, takie powstawanie doświadczeń estetycznych $\mathrm{w}$ umysłach wiąże się z określoną funkcją zjawiska z perspektywy ultymatywnej. Darwinowskie wyjaśnienie sugeruje, że nasze doświadczenie piękna muzycznego jest efektem nieświadomej oceny atrakcyjności seksualnej wykonawcy (Darwin, 1871; Miller, 2000). Niezależnie jaką funkcję ultymatywną muzyki uznamy za faktyczną przyczynę naszych doświadczeń estetycznych, czy będzie to popis seksualny (Miller, 2000), czy konsolidacja grupy (Roederer, 1984; Storr, 1992), opisywana przez przedstawicieli nauk humanistycznych funkcja estetyczna muzyki sprowadza się do rozumianej z perspektywy proksymalnej komunikacji określonego rodzaju informacji kulturowej, której rozpoznanie wzbudza u odbiorcy emocje estetyczne.

Czy zatem spór o to, czy muzyka pełni w pierwszym rzędzie funkcję estetyczną, czy komunikacyjną jest bezprzedmiotowy z perspektywy etologicznej? Byłoby tak, gdyby funkcje te miały identyczne przyczyny, tak w sensie proksymalnym, jak i ultymatywnym. Wydaje się jednak, że tak nie jest. O ile bowiem komunikacja muzyczna ma, przynajmniej w zakresie pewnych cech muzyki, takich jak np. struktura wysokościowa, charakter specyficzny nie tylko dla domeny audialnej, ale też dla samej komunikacji muzycznej, o tyle doświadczenie estetyczne nie jest ograniczone wyłącznie do domeny audialnej, ale też wizualnej, taktylnej, a nawet olfaktorycznej. Tak więc w obu wypadkach mamy do czynienia z komunikacją, jednak same mechanizmy tej komunikacji, a być może także i przyczyny ewolucyjne powstania tych mechanizmów są różne. Kiedy zatem w tradycyjnym dyskursie muzykologicznym mówi się o funkcji komunikacyjnej muzyki, ma się na myśli jej zdolność do przekazywania różnorakich informacji za pomocą systemu fonologicznego muzyki. Natomiast kiedy rozpatrujemy w tradycji humanistycznej funkcję estetyczną muzyki, odwołujemy się do zdolności wywoływania przez muzykę doświadczeń estetycznych, które odnoszą się do niespecyficznej dla muzyki kategorii piękna. W jakim stopniu jednak źródła archeologiczne mogą przyczynić się do oceny funkcji zachowań muzycznych naszych odległych w historii przodków?

\section{ŹRÓDLA ARCHEOLOGICZNE A MUZYKA}

W badaniach nad pierwotną muzycznością człowieka, poza odkryciami i wiedzą z zakresu takich dyscyplin naukowych, jak paleontologia, antropologia fizyczna, genetyka, etnologia i biologia ewolucyjna, jeśli wymienić tylko te najważniejsze, nieocenionym źródłem wiedzy są znaleziska archeologiczne. Wiele z tych znalezisk 
świadczy niewątpliwie o obecności zachowań muzycznych wśród naszych prahistorycznych przodków. Najbardziej przekonujące w tym względzie są znaleziska narzędzi, których budowa sugeruje ich muzyczne zastosowanie i skłania do określenia ich mianem instrumentów muzycznych, choć ważnym źródłem informacji o możliwych zachowaniach muzycznych mogą być też malowidła naskalne. Szczególnie cenne dla rozważań o początkach muzyczności człowieka są odkrycia najstarszych instrumentów muzycznych. W dyskusji nad początkami muzyki niekiedy to właśnie instrumenty muzyczne stają się głównym argumentem wskazywanym jako dowód pojawienia się muzyki (Higham i in., 2012). Należy jednak pamiętać, że zachowania muzyczne wczesnych Homo sapiens, a być może także innych homininów, nie musiały być związane z zastosowaniem jakichkolwiek narzędzi i mogły poprzedzać wynalezienie instrumentarium muzycznego o wiele lat (Morley, 2013, s. 32-33), a nawet tysiącleci (Mithen, 2006, 2009).

Samo odkrycie i datowanie artefaktów o wyglądzie instrumentu muzycznego nie musi wiązać się jednoznacznie z przypisaniem im funkcji muzycznych. Dobrym przykładem jest choćby niekończąca się dyskusja nad interpretacją znalezionego w słoweńskiej jaskini Divje Babe fragmentu kości z otworami przypominającymi flet. Według jednych badaczy jest faktycznym instrumentem muzycznym wykonanym i wykorzystywanym do aktywności muzycznej przez Homo neanderthalensis (Kunej, Turk, 2000; Tuniz i in., 2012; Turk i in., 2018), podczas gdy dla innych stanowi fragment kości nadgryzionej przez drapieżnika (D’Errico, Villa, 1997; Diedrich, 2015; Mithen, 2006; Morley, 2006). Osobnym problemem jest tu rozpoznanie, czy dźwięki wydobywane z tej piszczałki były wykorzystywane jako element muzyczny, czy może raczej jako wabik podczas polowania. Jeszcze więcej kontrowersji rodzi zastosowanie muzyczne narzędzi kamiennych, określanych mianem litofonów, zaliczanych do szerszej grupy instrumentów, tzw. idiofonów, wśród których na szczególną uwagę zasługują narzędzia krzemienne (Blake, Cross, 2008). Choć wykorzystanie różnych rodzajów kamienia jako źródła dźwięku wydaje się prawdopodobne, problemem jest ustalenie, czy ów przedmiot tylko wykorzystano do aktywności muzycznej, czy też intencjonalnie wykonano go z myślą o aktywności muzycznej. Odpowiedź negatywna na to drugie pytanie nie musi wiązać się z negatywną odpowiedzią na to pierwsze. Znanych jest bowiem wiele przykładów zastosowania muzycznego przedmiotów przeznaczonych pierwotnie do innych celów. Dobrym przykładem jest wskazywane przez etnomuzykologów używanie łuku jako instrumentu muzycznego przez przedstawicieli kultur zbieracko-łowieckich. Z drugiej strony, choć wykorzystywanie wiedzy etnomuzykologicznej do oceny potencjalnej „muzyczności” znalezisk archeologicznych może nieść ze sobą ważne przesłanki wspierające twierdzenia o muzycznym przeznaczeniu danych przedmiotów (Morley, 2013), należy pamiętać, że badania etnomuzykologiczne dokonywane są na współczesnych ludziach, których kultury mogą różnić się pod wieloma aspektami od kultur prehistorycznych. Jest to istotne zwłaszcza w przypadku analizy i interpretacji znalezisk, których wiek określany jest na dziesiątki tysięcy lat. Biorąc pod uwagę wskazane tu problemy, za najstarsze bezspornie instrumenty uważa się kościane flety znalezione w jaskiniach Hohle Fels, 
Vogelherd i Geißenklösterle, które znajdują się na terenie obecnych południowo-zachodnich Niemiec (Conard, Malina, Münzel, 2009). Wiek najstarszych z nich szacuje się na około 42-43 tys. lat (Higham i in., 2012).

\section{POCZĄTKI MUZYKI}

Kiedy należy szukać początków muzyczności w świetle wymienionych wyżej znalezisk archeologicznych? Jak już wspomniano, opieranie twierdzeń dotyczących początków muzyczności człowieka na odkryciach archeologicznych instrumentów muzycznych byłoby ryzykowne, ponieważ zachowania muzyczne ludzi nie muszą ograniczać się do muzyki instrumentalnej. Przeciwnie, bardziej prawdopodobne wydaje się, że zachowania te mają korzenie w aktywności wokalnej. Innymi słowy pierwszą formą muzyki był najprawdopodobniej śpiew (Bannan, 2012; Gorzelańczyk, Podlipniak, 2011, 2015b; Morley, 2013). Jedną z kluczowych cech struktury muzycznej jest wysokość dźwięku, dlatego ważną przesłanką dla rozważań o początkach muzyki jest stwierdzenie u naszych przodków zdolności do takiej kontroli aparatu głosowego, która umożliwia wolicjonalne operowanie częstotliwością dźwięków o strukturze harmonicznej, wytwarzanych za pomocą głosu. Zdaniem niektórych zdolnością taką być może wykazywał się już Homo heidelbergensis (Morley, 2013). Biorąc pod uwagę, że kontrola wokalna nad częstotliwością tonu podstawowego ( $\mathrm{F}_{\mathrm{o}}$ ) dźwięków o strukturze harmonicznej jest użyteczna jedynie, jeśli weźmiemy pod uwagę śpiew (Bannan, 2012; Podlipniak, 2016), początki muzyki mogą być o wiele starsze niż początki zastosowania instrumentów muzycznych. Wprawdzie intencjonalne operowanie częstotliwością wokalizacji ma też miejsce w mowie, szczególnie przy artykułowaniu słów $\mathrm{w}$ językach tonalnych, precyzja intonacyjna, do której konieczna jest wspomniana kontrola nad $\mathrm{F}_{\mathrm{o}}$, ma jednak zastosowanie jedynie przy wokalizacji konkretnych interwałów, stanowiących podstawę wysokościowego systemu muzycznego. Tym, co odróżnia śpiew od mowy, jest bowiem przede wszystkim dyskretny charakter wysokości dźwięku (Jackendoff, 2008; Zatorre, Baum, 2012), i choć w szczególnych okolicznościach ludzki umysł jest w stanie interpretować mowę jako śpiew (Deutsch, Henthorn, Lapidis, 2008, 2011), to nie ulega wątpliwości, że ważnym czynnikiem ułatwiającym muzyczną interpretację bodźca dźwiękowego jest stabilność $\mathrm{F}_{\mathrm{o}}$.

W świetle tych przesłanek nie można wykluczyć, że muzyczność jest starsza niż pierwsze instrumenty muzyczne, a być może także starsza niż Homo sapiens. Instrumenty muzyczne, takie jak kościane flety, byłyby wówczas wynalazkiem, który wspomagał stabilność $\mathrm{F}_{\mathrm{o}}$ podczas zbiorowych ekspresji muzycznych lub był po prostu narzędziem imitacji struktury muzycznej wokalizacji. Natomiast wszelkiego rodzaju idiofony, które nie generują dźwięków o strukturze harmonicznej, pełniłyby funkcję wspomagania lub imitacji muzycznej struktury metro-rytmicznej. Taka interpretacja rodzi oczywiście pytanie o to, dlaczego muzyka oparta na wokalizacji miałaby znacznie poprzedzać powstanie pierwszych instrumentów muzycznych. Zdaniem Stevena Mithena, należącego do tych badaczy, którzy szukają początków muzyczności jeszcze 
u przodków Homo sapiens (Mithen, 2009), przyczyna leży w braku zdolności wczesnych homininów do tworzenia skojarzeń intermodalnych (Mithen, 2006). Jeśli jednak nawet Mithen ma rację, jego propozycja nie wyjaśnia faktycznych motywów, jakie miałyby przyświecać twórcom pierwotnego instrumentarium. Innymi słowy, jaka funkcja adaptacyjna odpowiedzialna jest za powstawanie w umysłach twórców wczesnych instrumentów stanów motywacyjnych, które prowadzą do poświęcania czasu i energii na żmudne wytwarzanie narzędzi muzycznych. Jedną z możliwych odpowiedzi jest odwołanie się do idei artyfikacji.

\section{IDEA ARTYFIKACJI A MUZYKA}

Przyjmując perspektywę naturalistyczną nad badaniami zachowań artystycznych ludzi, warto odwołać się do ustaleń dotyczących biologicznych źródeł ludzkiej skłonności do uprawiania sztuki. Jeśli źródła te miałyby charakter adaptacyjny, byłyby odpowiedzialne za wspomniane generowanie emocjonalnych stanów motywacyjnych w umysłach twórców sztuki (Dissanayake, 1995), w tym także twórców instrumentów muzycznych. Skoro bowiem aktywności wokalnej wczesnych ludzi miałyby towarzyszyć jakiś zamysł artystyczny i doświadczenie estetyczne, które same w sobie stanowiłyby w tym ujęciu wspomniane stany motywacyjne, podobne do tych, które najprawdopodobniej towarzyszą ptakom podczas ich aktywności wokalnej (Rothenberg, Roeske, Voss, Naguib, Tchernichovski, 2014), zaangażowanie czasu i energii w wytwarzanie instrumentów byłoby niczym innym, jak reakcją na takie stany z odroczoną nagrodą. Mówiąc bardziej obrazowo, wcześniejsze doświadczenia estetyczne, przeżywane podczas wokalnej aktywności muzycznej, skłaniałyby twórców instrumentów do ich konstruowania i wytwarzania w nadziei na zwielokrotnienie tych doświadczeń za pomocą wytworzonego instrumentu dokładnie w taki sam sposób, w jaki przyjemne doświadczenia związane z zaspokajaniem głodu stały się wystarczającymi stanami motywującymi do konstruowania narzędzi myśliwskich. Nie ma powodu wątpić, że taki mechanizm odroczonej nagrody nie mógł być odpowiedzialny za powstanie sztuki. Należy tu podkreślić, że sztuka w tym ujęciu, a więc również muzyka, nie może być definiowana za pomocą arbitralnych wyborów społecznych, ale musi być traktowana jako obiektywne zjawisko o określonych cechach, których występowanie pozwala na odróżnienie sztuki od innych wytworów ludzkich (Dutton, 2009).

Jedną z ważnych i przekonujących propozycji teoretycznych, która może rzucić światło na przyczyny genezy obserwowanej wśród współczesnych ludzi uniwersalnej tendencji do estetyzacji wybranych aspektów doświadczanej rzeczywistości, w tym także elementów kultury wokalnej Homo sapiens, jest zaproponowana przez Ellen Dissanayake idea artyfikacji (Dissanayake, 1995, 2017; Malotki, Dissanayake, 2018). Artyfikacja to inaczej gatunkowo specyficzna predyspozycja Homo sapiens do uartystyczniania, czyli transformacji w sztukę zjawisk, które sztuką nie są. Predyspozycja ta miałaby być odpowiedzialna za skłonność ludzi do tworzenia przedmiotów o cechach trudnych do wyjaśnienia wyłącznie z perspektywy pragmatycznej. Ponieważ 
jednak ekspresje muzyczne nie mają postaci stabilnych przedmiotów, ale są realizowane przez wytwarzanie fali akustycznej, która dostępna jest zmysłowo jedynie w jednorazowym akcie słuchowym, artyfikacja musiałaby oznaczać w tym wypadku nie tyle skłonność do tworzenia przedmiotów, co raczej szerzej rozumianą potrzebę do wyrażania w specyficzny sposób swoich intencji estetycznych. Pogląd taki stoi w zbieżności z hipotezą Dissanayake (2017), że artyfikacja ma korzenie w „proto-artystyczno-estetycznych" zachowaniach, charakteryzujących interakcję matki z niemowlęciem. Choć zachowania te same w sobie nie są jeszcze przejawem artyfikacji, to stały się punktem wyjścia do jej ewolucji. Ponieważ interakcje te, podobnie jak muzyka, mają ulotny charakter temporalny, jedną z konsekwencji scenariusza zaproponowanego przez Dissanayake jest powstanie sztuk czasowych, w tym muzyki (Dissanayake, 2001). Nie trzeba dodawać, że z tej perspektywy funkcja estetyczna muzyki jest jej niezbywalnym i pierwotnym atrybutem.

Czy jednak faktycznie muzyczne zachowania wokalne mają charakter artystyczny? Nawet dziś wiele ekspresji wokalnych, posiadających wskazane wcześniej warunki konieczne do rozpoznania w nich struktury muzycznej, trudno jednoznacznie uznać za przejawy aktywności artystycznej lub chociażby prowadzącej do doświadczeń estetycznych. Wiele ze śpiewów obserwowanych zarówno we współczesnych kulturach plemiennych, jak również społeczeństwach tworzących cywilizacje ma charakter rytuałów pozbawionych cech artystycznych, jak wszelkiego rodzaju śpiewy wojenne albo pieśni stadionowe. Czy zjawiska te są bliższe pierwotnej muzyce, czy stanowią raczej rodzaj stosunkowo młodego „wynalazku” kulturowego polegającego na wykorzystaniu istniejących cech struktury muzyki - sztuki do pełnienia nieartystycznych funkcji? Innymi słowy, czy śpiewy stadionowe podobne są do zjawisk takich jak ,języki bębnione” lub ,języki gwizdane” (Meyer, 2015), które polegają najprawdopodobniej na wtórnym wykorzystaniu cech systemu fonologicznego muzyki w celu komunikacji językowej? Czy może komunikacyjny charakter rytuałów muzycznych, związany najprawdopodobniej z adaptacyjną funkcją konsolidacyjną (Launay, Tarr, Dunbar, 2016; Podlipniak, 2015a; Storr, 1992; Weinstein, Launay, Pearce, Dunbar, Stewart, 2016), stanowi pierwotną funkcję muzyki?

\section{GENEZA CHARAKTERU ESTETYCZNEGO MUZYKI}

Podstawowe pytanie, jakie nasuwa się przy rozpatrywaniu pierwotnej funkcji muzyki oraz jej ewentualnego charakteru estetycznego, dotyczy kwestii istnienia związku między pierwszymi muzycznymi wokalizacjami naszych przodków a możliwym ich doświadczeniem estetycznym. Ważnym argumentem wskazującym na jego brak w pierwotnych wokalizacjach mogą okazać się właśnie znaleziska archeologiczne. Jeśli bowiem uznamy, że muzyka jest dużo wcześniejsza od instrumentów muzycznych, to pojawienie się zaawansowanego technologicznie instrumentarium dopiero z rewolucją kulturową górnego paleolitu sugeruje, że to potrzeba „uartystyczniania”, a nie „muzykowania” samego w sobie była główną przyczyną wynalezienia instru- 
mentu muzycznego. Pojawienie się sztuki wizualnej i jej proliferacja wiązały się najprawdopodobniej z potrzebą intencjonalnej kontemplacji estetycznej. Bez tej potrzeby trudno wyobrazić sobie przyczyny powstania stanów motywacyjnych stojących za tworzeniem kościanych fletów przez naszych domniemanych przodków z jaskiń Hohle Fels, Vogelherd i Geißenklösterle. Do wypełniania funkcji konsolidacyjnej rytuałów muzycznych zupełnie wystarczająca była aktywność wokalna, realizowana z definicji wyłącznie w domenie audialnej. Dopiero potrzeba doznań estetycznych uzyskiwanych za pomocą różnych modalności skłoniła ich do skonstruowania, a następnie wykorzystania instrumentów do wzbogacenia aktywności muzycznej i tym samym zwielokrotnienia możliwości ekspresji artystycznej.

\section{PODSUMOWANIE}

Wskazana koncepcja genezy funkcji estetycznej muzyki, późniejszej niż funkcji komunikacyjnej, ma, rzecz jasna, charakter spekulatywny z uwagi na brak bezpośrednich źródeł muzycznych działań naszych przodków (lub homininów, którzy nie są nimi bezpośrednio). Nie sposób stwierdzić nawet, jakie były faktyczne motywacje stojące za wytwarzaniem pierwszych znanych nam instrumentów. Na obecnym etapie badań traktowanie funkcji estetycznej muzyki jako pierwotnej wydaje się trudne do utrzymania. Muzyka, która charakteryzuje się strukturą wysokościową, najprawdopodobniej towarzyszyła człowiekowi długo przed rewolucją kulturową górnego paleolitu. Niemniej powstanie instrumentarium muzycznego w tamtym okresie, a więc ponad 40 tys. lat temu, dowodzi, że muzyczność musiała stanowić ważny element kultury Homo sapiens. W świetle wskazanych przesłanek jednym z czynników proksymalnych, odpowiedzialnych za jej obecność w społecznościach ludzkich górnego paleolitu, były najprawdopodobniej emocje estetyczne. Osobnym zagadnieniem jest tu oczywiście problem funkcji adaptacyjnej, która miałaby być przyczyną ewolucji tych emocji. Pytanie o nią dotyczy jednak dużo szerszego zagadnienia niż kwestia pierwotności funkcji estetycznej muzyki.

\section{BIBLIOGRAFIA}

Bannan, N.

2012 Harmony and its Role in Human Evolution. W: N. Bannan (red.), Music, Language, and Human Evolution (s. 288-340). Oxford: Oxford University Press. https://doi.org/10.1093/ acprof:osobl/9780199227341.003.0012

Behne, K.-E.

1997 The development of „Musikerleben” in adolescence: How and why young people listen to music. W: Perception and cognition of music (s. 143-159). Hove, England: Psychology Press/Erlbaum (UK) Taylor \& Francis.

Blacking, J.

1973 How musical is man? Seattle - London: University of Washington Press. 
Blake, E. C., Cross, I.

2008 Flint Tools as Portable Sound-Producing Objects in the Upper Palaeolithic Context: An Experimental Study. W: P. Cunningham, J. Heeb, R. Paardekooper (red.), Experiencing archaeology by experiment (s. 1-19). Oxford: Oxbow Books.

Brown, S., Merker, B., Wallin, N. L.

2000 An introduction to evolutionary musicology. W: N. L.Wallin, B. Merker, S. Brown (red.), The Origins of Music (s. 3-24). Cambridge, London: The MIT Press.

Cady, E. T., Harris, R. J., Knappenberger, J. B.

2008 Using music to cue autobiographical memories of different lifetime periods. Psychology of Music, 36(2), 157-177. https://doi.org/10.1177/0305735607085010

Conard, N. J., Malina, M., Münzel, S. C.

2009 New flutes document the earliest musical tradition in southwestern Germany. Nature, 460(7256), 737-740. https://doi.org/10.1038/nature08169

Cook, N.

2000 Muzyka. Bardzo krótkie wprowadzenie. Warszawa: Prószyński i S-ka.

D’Errico, F., Villa, P.

1997 Holes and grooves: the contribution of microscopy and taphonomy to the problem of art origins. Journal of Human Evolution, 33(1), 1-31. https://doi.org/10.1006/ JHEV.1997.0141

Dahlhaus, C., Eggebrecht, H. H.

1992 Co to jest muzyka? Tłum. D. Lachowska. Warszawa: PIW.

Darwin, C.

1871 The descent of man, and selection in relation to sex (1. wyd.). London: John Murray.

Deutsch, D., Henthorn, T., Lapidis, R.

2008 The speech-to-song illusion. The Journal of the Acoustical Society of America, 124(4), 2471. https://doi.org/10.1121/1.4808987

Deutsch, D., Henthorn, T., Lapidis, R.

2011 Illusory transformation from speech to song. The Journal of the Acoustical Society of America, 129(4), 2245-2252. https://doi.org/10.1121/1.3562174

Diedrich, C. G.

2015 „Neanderthal bone flutes”: Simply products of Ice Age spotted hyena scavenging activities on cave bear cubs in European cave bear dens. Royal Society Open Science, 2(4), 140022-140022. https://doi.org/10.1098/rsos.140022

Dissanayake, E.

1995 Homo aestheticus: Where art comes from and why. Seattle: University of Washington Press.

Dissanayake, E.

2001 Antecedents of the temporal arts in early mother-infant interaction. W: N. L. Wallin,

B. Merker, S. Brown (red.), The origins of music (s. 389-410). Cambridge: MIT Press.

Dissanayake, E.

2017 Roots and Route of the Artification Hypothesis. Avant, 8(1), 15-32. https://doi. org/10.26913/80102017.0101.0001

Dunbar, R. I. M.

2012 On the Evolutionary Function of Song and Dance. W: N. Bannan (red.), Music, Language, and Human Evolution (s. 201-214). Oxford: Oxford University Press. https://doi. org/10.1093/acprof:osobl/9780199227341.003.0008

Dutton, D.

2009 The art instinct: Beauty, pleasure, \& human evolution. New York: Bloomsbury Press.

Fitch, W. T.

2006 The biology and evolution of music: A comparative perspective. Cognition, 100(1), 173215. https://doi.org/10.1016/J.COGNITION.2005.11.009 
Fitch, W. T.

2013 Rhythmic cognition in humans and animals: Distinguishing meter and pulse perception. Frontiers in systems neuroscience, 7, 68. https://doi.org/10.3389/fnsys.2013.00068

Fitch, W. T.

2015 Four principles of bio-musicology. Philosophical Transactions of the Royal Society of London B: Biological Sciences, 370(1664), 20140091. https://doi.org/10.1098/rstb.2014.0091

Gorzelańczyk, E. J., Podlipniak, P.

2011 Human singing as a form of bio-communication. Bio-Algorithms and Med-Systems, 7(2), 79-83.

Higham, T., Basell, L., Jacobi, R., Wood, R., Ramsey, C. B., Conard, N. J.

2012 Testing models for the beginnings of the Aurignacian and the advent of figurative art and music: The radiocarbon chronology of Geißenklösterle. Journal of Human Evolution, 62(6), 664-676. https://doi.org/10.1016/J.JHEVOL.2012.03.003

Husain, G., Thompson, W. F., Schellenberg, E. G.

2002 Effects of Musical Tempo and Mode on Arousal, Mood, and Spatial Abilities. Music Perception, 20(2), 151-171. https://doi.org/10.1525/mp.2002.20.2.151

Jabłoński, M.

2010 Music as sign. Hakapaino: International Semiotics Institute.

Jackendoff, R.

2008 Parallels and Nonpararelles between Language and Music. Music Perception, 26(3), 195204.

Jackendoff, R., Lerdahl, F.

2006 The capacity for music: what is it, and what's special about it? Cognition, 100(1), 33-72. https://doi.org/10.1016/j.cognition.2005.11.005

Kunej, D., Turk, I.

2000 New Perspectives on the Beginnings of Music: Archeological and Musicological Analysis of a Middle Paleolithic Bone „Flute”. W: N. L. Wallin, B. Merker, S. Brown (red.), The origins of music (s. 235-268). Cambridge, MA, US: The MIT Press.

Laland, K. N.

2017 Darwin's unfinished symphony: How culture made the human mind. Princeton, Oxford: Princeton University Press.

Launay, J., Tarr, B., Dunbar, R. I. M.

2016 Synchrony as an Adaptive Mechanism for Large-Scale Human Social Bonding. Ethology, 122(10), 779-789. https://doi.org/10.1111/eth.12528

Malinowski, B.

1987 Seks $i$ stlumienie $w$ społeczności dzikich oraz inne studia o ptci, rodzinie $i$ stosunkach pokrewieństwa. Przekł. J. Chałasiński. Warszawa: PWN.

Malotki, E., Dissanayake, E.

2018 Early rock art of the American West: The geometric enigma. Seattle: University of Washington Press.

Merriam, A. P.

1964 The anthropology of music. Evanston - Illinois: Northwestern University Press.

Meyer, J.

2015 Whistled languages: A worldwide inquiry on human whistled speech. New York: Springer-Verlag.

Miller, G. F.

2000 Evolution of Human Music Through Sexual Selection. W: N. L. Wallin, B. Merker, S. Brown (red.), The Origins of Music (s. 329-360). Cambridge: The MIT Press. https:// doi.org/10.1177/004057368303900411 
Mithen, S. J.

2006 The singing Neanderthals: The origins of music, language, mind, and body. Cambridge: Harvard University Press.

Mithen, S. J.

2009 The music instinct: The evolutionary basis of musicality. Annals of the New York Academy of Sciences, 1169, 3-12. https://doi.org/10.1111/j.1749-6632.2009.04590.x

Morley, I. 2006

Mousterian Musicianship? The Case of the Divje Babe I Bone. Oxford Journal of Archaeology, 25(4), 317-333. https://doi.org/10.1111/j.1468-0092.2006.00264.x

Morley, I.

2013 The prehistory of music: Human evolution, archaeology, and the origins of musicality. New York: Oxford University Press.

North, A. C., Hargreaves, D. J.

2000 Musical Preferences during and after Relaxation and Exercise. The American Journal of Psychology, 113(1), 43-67. https://doi.org/10.2307/1423460

Podlipniak, $\mathrm{P}$.

2015a Instynkt tonalny. Koncepcja ewolucyjnego pochodzenia tonalności muzycznej. Poznań: Wydawnictwo Naukowe UAM.

Podlipniak, $\mathrm{P}$.

2015b The origin of music and the Baldwin effect. W: J. Ginsborg, A. Lamont, S. Bramley (red.), Proceedings of Ninth Triennial Conference of the European Society for the Cognitive Sciences of Music (s. 671-677). Manchester: Royal Northern College of Music.

Podlipniak, $\mathrm{P}$.

2016 The evolutionary origin of pitch centre recognition. Psychology of Music, 44(3), 527-543. https://doi.org/10.1177/0305735615577249

Prum, R. O.

2017 The evolution of beauty: How Darwin's forgotten theory of mate choice shapes the animal world-and us. New York: Doubleday.

Roederer, J. G.

1984 The Search for a Survival Value of Music. Music Perception: An Interdisciplinary Journal, 1(3), 350-356. https://doi.org/10.2307/40285265

Roosth, S.

2018 Nineteen Hertz and Below: An Infrasonic History of the Twentieth Century. Resilience: A Journal of the Environmental Humanities, 5(3), 109-124. https://doi.org/10.5250/resilience.5.3.0109

Rothenberg, D., Roeske, T. C., Voss, H. U., Naguib, M., Tchernichovski, O.

2014 Investigation of musicality in birdsong. Hearing Research, 308, 71-83. https://doi. org/10.1016/j.heares.2013.08.016

Schulkind, M. D., Hennis, L. K., Rubin, D. C.

1999 Music, emotion, and autobiographical memory: They're playing your song. Memory \& Cognition, 27(6), 948-955. https://doi.org/10.3758/BF03201225

Storr, A.

1992 Music and the mind. New York: Ballantine Books.

Tarr, B., Launay, J., Dunbar, R. I. M.

2014 Music and social bonding: „Self-other” merging and neurohormonal mechanisms. Frontiers in Psychology, 5(1096). https://doi.org/10.3389/fpsyg.2014.01096

Thoma, M. V., La Marca, R., Brönnimann, R., Finkel, L., Ehlert, U., Nater, U. M.

2013 The Effect of Music on the Human Stress Response. PLoS ONE, 8(8), e70156. https://doi. org/10.1371/journal.pone.0070156 
Tinbergen, $\mathrm{N}$.

1963 On aims and methods of ethology. Zeitschrift für Tierpsychologie, 20(4), 410-433. https:// doi.org/10.1111/j.1439-0310.1963.tb01161.x

Tuniz, C., Bernardini, F., Turk, I., Dimkaroski, L., Mancini, L., Dreossi, D.

2012 Did Neanderthals play music? X-Ray computed micro-tomography of the Divje Babe 'flute'. Archaeometry, 54(3), 581-590. https://doi.org/10.1111/j.1475-4754.2011.00630.x

Turk, M., Turk, I., Dimkaroski, L., Blackwell, B. A. B., Horusitzky, F. Z., Otte, M., Bastiani, G., Korat, L.

2018 The Mousterian Musical Instrument from the Divje Babe I cave (Slovenia): Arguments on the Material Evidence for Neanderthal Musical Behaviour. L'Anthropologie, 122(4), 679-706. https://doi.org/10.1016/J.ANTHRO.2018.10.001

Weinstein, D., Launay, J., Pearce, E., Dunbar, R. I. M., Stewart, L.

2016 Singing and social bonding: Changes in connectivity and pain threshold as a function of group size. Evolution and Human Behavior, 37(2), 152-158. https://doi.org/10.1016/j. evolhumbehav.2015.10.002

Zatorre, R. J., Baum, S. R.

2012 Musical melody and speech intonation: Singing a different tune. PLoS Biology, 10(7), Article ID e1001372. https://doi.org/10.1371/journal.pbio.1001372

\title{
THE ISSUE OF THE PRIMORDIALITY OF THE AESTHETIC FUNCTION OF MUSIC IN THE LIGHT OF ARCHEOLOGICAL DISCOVERIES
}

\author{
Sum mary
}

The article states that the primal function of music was communication. In the proposed concept, the music gained its aesthetic function together with the cultural revolution from the Upper Paleolithic period. To argue for the mentioned argument, in the article, I present the necessity of using a naturalistic paradigm in studies on the beginnings of the music. Because accepting the mentioned paradigm requires determining if the musicality is part of human nature, there is a necessity to define what we understand user the term "music". Thus, we cannot look for the traces of the first musicality when we do not determine what it is. Therefore, at the beginning of the article, I presented the flaws of, widespread in humanistic and social sciences, the so-called open definition of music which refers to social, and culturally changing understanding of what we describe under the term "music". As an alternative to the open definition of music, there is a definition that refers to distinguishing the conditions necessary to define something as music. Then, music is such human sound activity which bases on arranging discrete categories of sound amplitude in time or/and hierarchization of sound actions in time in a periodical and hierarchical way.

For the studies presented in the article, it is essential to show ways of determining and understanding the functions of music. Therefore, in the following parts, I present the issues connected to the impurity of the term "function" in various scientific disciplines which study music. There are various functions of music mentioned here, starting from the aesthetic function, often treated as the most significant one, through communicative, which was a base for development of a sub-discipline - musicology, the semiotics of music, and also the function of enhancing social bonds or empowering the ritual, inducing autobiographical memories, regulating mood, and overcoming emotional crisis. Despite the lack of one perspective in determining the functions as mentioned above of music by the representatives of various scientific disciplines, I argue that the naturalistic paradigm that is 
postulated in the articles might be a shared approach. However, to gain it, I presume the need to reduce the aesthetic and communicative functions - terms traditionally linked to humanistic and social sciences - to the biological categories.

Another part of the article is a short presentation of the contemporary knowledge on the archaeological findings interpreted as the oldest musical tools and the leading causes of the arguments of their interpretation. In the article, I mention the issues connected to the analysis of the fragment of bone with holes resembling flute. The object was discovered in the Divie Babe cave in Slovenia in the Neanderthal settlements. Another issue concerns the possible musical usage of flint tools as lithophone - drum instruments made of rock. In both cases, the discovery and dating of artifacts resembling musical instruments do not equal with adding the musical functions. The main issue here is to recognize the possible usage of such tools as musical instruments and the possibility of identification of the intentional using such devices to the musical activity or/and deliberate production of a tool to create music. Although using ethnomusicological knowledge seems to be very useful to interpret the possible usage of an archaeological artifact as a musical instrument, there are some disadvantages of such studies: the ethnomusicological studies are conducted among the contemporary societies whose culture may differ in many aspects from the prehistoric ones. As the critical elements for the studies, the indisputable examples of the oldest musical instruments are mentioned, these are flutes made of bones found on the area of today's' south-western Germany, dated back to 42.000-43.000 years (the oldest ones).

Another issue elaborated in the article is the discussion on the beginnings of human musicality. I point out that basing the interpretation of the beginnings of the human musicality on the archaeological artifacts is disputable. The musical activities of the past people did not have to be limited to instrumental music. As an alternative method of research I propose to use the anthropological and ethnological knowledge, first and foremost the proceedings of these disciplines connected to the ability to control the voice apparatus on the volitional operation of sounds wavelength, especially those of harmonic structure of which the vocalization of hominids consists. Taking into account that the anatomical features which allow such control are much older than the oldest archaeological findings of musical instruments, I argue that the beginning of music is much older than the beginning of usage of musical instruments, and they are connected to singing. It is possible that the ability to control the voice apparatus to sing was present among Homo heidelbergensis. In that part, I also present the arguments which show the connection between some physiological features, such as mentioned control of the wavelength of vocal expressions, only with singing, as phenomenon characteristic for human vocalization.

To validate later than the communication appearance of the aesthetical function of music, I used the idea of artification proposed by Ellen Dissanayake. The approach argues that the Homo sapiens had the natural ability to create art and interpret various stimuli in the aesthetic categories. In other words, it is a unique feature of Homo sapiens to transform the non-artistic phenomena into art. This ability, on a physiological level, discloses thanks to inducing emotional states of motivation in the minds of authors and recipients of art. It is shown that such states might have been present among the first creators of music instruments, and they could have motivated them to devote more time and energy for the later award in the form of multiplied aesthetic experiences induced by the usage of musical activity of musical instruments. From that perspective, the aesthetic impressions were experienced by people only when they had had the mentioned ability. Therefore, due to the lack of as old archaeological findings as the ability to the "musical" control of voice apparatus, it seems to be justified to state that the emotional states of motivation connected to the aesthetic experiences had not been present from the very beginning of musicality. Such interpretation makes it possible that the aesthetic function of music appeared together with the Upper Paleolithic cultural revolution. 
In the summary, I present problems connected to the lack of any direct sources of the prehistoric musicality, the link between the origins of human musicality, as well as the proposed hypothesis of later appearance of the aesthetic function of music in comparison to its communicative function, with such widely disputed issued as function and origin of aesthetic emotion of human beings, and their specificity to chosen forms of artistic activities of contemporary public. 